\title{
Analysis of Business Decisions that caused Nokia to drop its Legacy and its Rebirth in 2017 using Nostalgic Marketing Approach: A Case Study
}

\author{
Vijay raj B. V. ${ }^{1}$ \& A. Jayanthila Devi ${ }^{2}$ \\ ${ }^{1}$ Research Scholar, College of Computer Science and Information Science, Srinivas \\ University, Mangalore, Karnataka, India and Assistant Professor, Dept. of Computer Science, \\ The National College, Jayanagar, Bengaluru, Karnataka, India. \\ ORCID: 0000-0002-4539-2245; Email: vijayrajbv13@gmail.com \\ ${ }^{2}$ Research Professor, College of Computer Science \& Information Science, Srinivas \\ University Mangalore - 575001, India. \\ ORCID: 0000-0002-6023-3899; Email: jayanthilamca@gmail.com
}

Area of the Paper: Computer Science

Type of the Paper: Research Case Study

Type of Review: Peer Reviewed as per $|\mathrm{C}| \mathrm{O}|\mathrm{P}| \mathrm{E} \mid$ guidance.

Indexed In: OpenAIRE.

DOI: https://doi.org/10.5281/zenodo.5764564

Google Scholar Citation: IJCSBE

\section{How to Cite this Paper:}

Vijay raj, B. V., \& Jayanthila Devi, A., (2021). Analysis of Business Decisions that caused Nokia to drop its Legacy and its Rebirth in 2017 using Nostalgic Marketing Approach: A Case Study. International Journal of Case Studies in Business, IT, and Education (IJCSBE), 5(2), 268-283. DOI: https://doi.org/10.5281/zenodo.5764564

International Journal of Case Studies in Business, IT and Education (IJCSBE)

A Refereed International Journal of Srinivas University, India.

Crossref DOI : https://doi.org/10.47992/IJCSBE.2581.6942.0133

(C) With Authors.

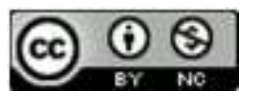

This work is licensed under a Creative Commons Attribution Non-Commercial 4.0 International License subject to proper citation to the publication source of the work.

Disclaimer: The scholarly papers as reviewed and published by the Srinivas Publications (S.P.), India are the views and opinions of their respective authors and are not the views or opinions of the S.P. The S.P. disclaims of any harm or loss caused due to the published content to any party. 


\title{
Analysis of Business Decisions that caused Nokia to drop its Legacy and its Rebirth in 2017 using Nostalgic Marketing Approach: A Case Study
}

\author{
Vijay raj B. V. ${ }^{1}$ \& A. Jayanthila Devi ${ }^{2}$ \\ ${ }^{1}$ Research Scholar, College of Computer Science and Information Science, Srinivas \\ University, Mangalore, Karnataka, India and Assistant Professor, Dept. of Computer Science, \\ The National College, Jayanagar, Bengaluru, Karnataka, India. \\ ORCID: 0000-0002-4539-2245; Email: vijayrajbv13@gmail.com \\ ${ }^{2}$ Research Professor, College of Computer Science \& Information Science, Srinivas \\ University Mangalore - 575001, India. \\ ORCID: 0000-0002-6023-3899; Email: jayanthilamca@gmail.com
}

\begin{abstract}
Purpose: This article will investigate the causes for Nokia's failure to stay afloat in the market, as well as how the company resurrected in 2017 by employing a nostalgic or sentimental marketing strategy. Technology management on a strategic level at Nokia Corporation is thoroughly examined and analyzed in this study. Nokia used to be the market's dominant corporation, leader, and pacesetter until it had a massive market disaster. We inferred that the problem at Nokia was not the absenteeism of advancement, but in its place, it was due to a lack of innovation estimation and a misunderstanding that the requirements in the mobile phone market were not only about displaying a cell phone that makes verdicts, sends messages, and connects to the internet, but also the stage that connects all of these volumes together. Finally, this article describes how Nokia's revival was achieved through the use of a nostalgic or sentimental marketing strategy.

Objectives: We aim to present the reasons behind the failure of Nokia and its return using Nostalgic marketing approach to do a comparison analysis with its competitors and make recommendations to improve the company based on the findings

Design/Methodology/Approach: Journals, as well as a variety of internet resources such as websites and blogs, were used to conduct this company analysis. A SWOC Analysis was used to analyses the Nokia corporation.

Findings/Result: Till 2008 Nokia was the pioneer in the mobile phone market. Based on the study done it's clear that Nokia failed to acquire smart phone market because Nokia couldn't recognize the customer needs, didn't Analyze the Market Accurately and also lack of implementing innovative technology in its product which customer needs. Nokia was focusing on implementing traditional Symbian operating system to its smart phone but Samsung choose android as its operating systems for its smartphone at the right time, which met the customer requirements. In 2017 Nokia came with nostalgic marketing approach by re-creating its old Nokia 3310 handset with modern features such Bluetooth, GPS, Wifi.

Originality/Value: Based on data from secondary sources, this article investigates the reasons why Nokia failed to gain access to the smartphone market, and explores its comeback through nostalgic marketing strategies.
\end{abstract}

Paper Type: Research Case Study.

Keywords: Nokia, Nostalgic marketing strategy, Forecasting, Innovation, Misjudging, Business decision, SWOC Analysis

\section{INTRODUCTION :}

Nokia was one of the wireless phone makers to enter the India market in the mid-1990s and the brand nearly became nonexclusive to PDAs. Around the world, cell phones were utilized by 1.85 billion 
individuals in 2014. This number is relied upon to be 2.32 billion of every 2017 and 2.87 billion out of 2020 [1]. The situation on the Indian market was altogether more grounded than in the widespread market. Moreover, the Indian cell phone market filled quickly in the mid-1990s and Nokia even opened one of its biggest creation offices in India. In any case, alongside the remainder of the world, Nokia lost its driving situation in India and the worldwide market as it couldn't benefit from the cell phone pattern [2]. Nokia was one of the dominant cell phone market leaders until 2007, started to face huge race after apple introduced its advanced and unique screen touch cell phone called iPhone to the market. Due to underestimating the customer needs it started to face huge race, but still Nokia came with good smartphone to sustain its market leadership with windows operating system. But it didn't reach the goal. As a result, Nokia offered its handset business to Microsoft for an aggregate of $\$ 5$ billion, Nokia likewise allows Microsoft to get to its licenses for a very long time for another $\$ 2,2$ billion in 2013.After the deal, Nokia started to zero in more broadly on its media transmission business and on its Internet of things [3]. After Completing deal with Microsoft in 2016, Nokia confirmed its plan to reenter the industry it once dominated. Nokia plans to start connecting people once again in collaboration with HMD Global. Nokia has been a set up generally speaking brand and a huge market player in adaptable industry. It transformed into an overall beast in handsets market since it could expect the colossal premium for adaptable handsets which various firms couldn't foresee. But, since 2008, Nokia has been deserted by its foes in the improvement arranged Smartphone market [4]. For an impressive timeframe, Nokia has been the best player in the cell market, since 2008, the association has been losing progressively a greater amount of its advantage and fights with a reducing slice of the pie, falling deal costs and a declining status [5]. This article attempts to explain the main reasons why Nokia has fallen from the mobile phone market leader to the former mobile phone manufacturer in less than 10 years, and explains how nostalgic or sentimental marketing strategies have helped it regain its glory.

\section{RELATED WORK :}

Table 1 summarizes the contributions of various authors about Reasons that caused Nokia's to lose its market all over the world.

Table 1: Summary of findings by different authors

\begin{tabular}{|l|l|l|l|}
\hline SI. No & \multicolumn{1}{|c|}{ Author(s) } & Year & \multicolumn{1}{c|}{ Findings/Result } \\
\hline 1 & Chaturvedi (2017) [2]. & 2017 & $\begin{array}{l}\text { The author Analyzed the decline of Nokia into Three } \\
\text { phases and Recommended advertising systems to bring } \\
\text { back the lost market. }\end{array}$ \\
\hline 2 & $\begin{array}{l}\text { Bhalodiya N. \& } \\
\text { Sagotia, N. (2018) [3]. }\end{array}$ & 2018 & $\begin{array}{l}\text { Discuss the Details Behind the failure of Nokia \& } \\
\text { Proposed suggestions to gain its legacy }\end{array}$ \\
\hline 3 & Neelu (2014) [4]. & 2014 & $\begin{array}{l}\text { The author surveys the present condition of Nokia in } \\
\text { versatile industry and the future possibilities. }\end{array}$ \\
\hline 5 & $\begin{array}{l}\text { Sehrawat, S. (2019) } \\
\text { [5]. } 2019\end{array}$ & $\begin{array}{l}\text { The author distinguishes and analyzed the nature and } \\
\text { Business methodologies of the enormous worldwide } \\
\text { organization 'Nokia' and furthermore investigates the } \\
\text { example and drivers of hazard the executives. }\end{array}$ \\
\hline 6 & Hira. A. (2012) [6]. & 2012 & $\begin{array}{l}\text { The author reveals the mystery behind accomplishment } \\
\text { of Nokia and closed in light of its planning and } \\
\text { intercessions Nokia accomplished an achievement } \\
\text { cellphone market. }\end{array}$ \\
\hline 7 & Sulphey M. (2019) [8]. 2019 & $\begin{array}{l}\text { Investigated the Nokia Firm and finished up } \\
\text { disappointment of the board in settling on proper choice } \\
\text { which drove Nokia to lose its market. }\end{array}$ \\
\hline $\begin{array}{l}\text { The author Clarifies Adoption of Organizational } \\
\text { Ambidextrousness would Have Changed the History of } \\
\text { Nokia and wrapped up the accomplishment of Nokia } \\
\text { would have been changed if it had followed misuse and } \\
\text { examination simultaneously. }\end{array}$ \\
\hline
\end{tabular}




\begin{tabular}{|l|l|l|l|}
\hline 8 & Bhatt P. R. (2002) [9]. & 2002 & $\begin{array}{l}\text { Investigates the historical backdrop of Nokia and its } \\
\text { monetary presentation and furthermore its innovation } \\
\text { improvement from 1998 }\end{array}$ \\
\hline 9 & Kalyani P. (2017) [10]. & 2017 & $\begin{array}{l}\text { Made an Empirical Study on Nokia's Nostalgic } \\
\text { Marketing Approach and its come back in 2017 }\end{array}$ \\
\hline 10 & $\begin{array}{l}\text { Bidyarthi, H. M. J., et } \\
\text { al (2011) [12] }\end{array}$ & 2011 & $\begin{array}{l}\text { The authors investigate the Nokia's prosperity } \\
\text { procedures during the years 2002 - 2006 in Indian } \\
\text { versatile phones marketplace driven simply by its } \\
\text { individual promoting direction which recommends } \\
\text { different administration guidelines. }\end{array}$ \\
\hline 11 & $\begin{array}{l}\text { Bouwman, Harry et al. } \\
\text { (2014) [13] }\end{array}$ & $\begin{array}{l}\text { The authors Concluded that a firm need a dynamic } \\
\text { advancement strategy, late in item dispatch and market } \\
\text { division system disappointment made Nokia un-nail the } \\
\text { cellphone market. }\end{array}$ \\
\hline 12 & $\begin{array}{l}\text { Tyagi, P., \& Zaidi, } \\
\text { neha. (2019) 2019 [15]. }\end{array}$ & $\begin{array}{l}\text { The authors inspect the qualities of the significant } \\
\text { portable working frameworks, like iOS, Android, and } \\
\text { Windows Phone, makes examinations dependent on key } \\
\text { norms. }\end{array}$ \\
\hline 13 & $\begin{array}{l}\text { Bharati Wukkadada et } \\
\text { al (2015) [19]. }\end{array}$ & $\begin{array}{l}\text { Salman Abdou, D. M., } \\
\& \text { Hussein, R. (2020) } \\
\text { [23]. } 2020\end{array}$ & $\begin{array}{l}\text { The authors examine the characteristics of the major } \\
\text { mobile operating systems, such as iOS, Android, and } \\
\text { Windows Phone, makes comparisons based on key } \\
\text { standards. }\end{array}$ \\
\hline $\begin{array}{l}\text { The authors extravagantly examine and investigate the } \\
\text { disappointment reasons and highlights the elements like } \\
\text { smugness, dread of progress and absence of } \\
\text { bevelopment which made a course Nokia to lose its } \\
\text { market. }\end{array}$ \\
\hline 15
\end{tabular}

\section{OBJECTIVES OF THE STUDY :}

The Objectives of the study are:

(1) To understand history of Nokia

(2) To know Nokia legacy in the cell phone market.

(3) To understand the issues and vulnerabilities of the Nokia.

(4) To do a SWOC analysis of the company.

(5) To analyze the strategic decisions that led Nokia to lose its legacy.

(6) To study how nostalgic marketing strategies helped Nokia regain its fame.

(7) To provide suggestions based on the current trend.

\section{METHODOLOGY :}

The data and information for this article were gathered through secondary sources such as blogs, journal articles, magazines, as well as official website Nokia.

\section{HISTORY OF NOKIA :}

The name, 'Nokia' really began from a Finnish town called Nokia, and furthermore the Nokianvirta stream. It is a worldwide organization initially began in 1865 by Fredrik Idestam [11]. Nokia was started in 1865 in Finland by Fredrik Idestam as a wood pound plant by the name Nokia Aktiebolag. Finland is an odd spot for the development of a worldwide rival in IT. With a little homegrown populace of 5.2 million, a somewhat distant area, and a conventional economy dependent on regular assets (wood, mash, 
and paper) [6]. Some place in the scope of 1918 and 1922, Nokia had been one of the biggest Finnish organizations since the 1960s and was an enormous organization since the time its nineteenth century establishing as a paper-industry organization [7]. Finnish Rubber Works Ltd. obtained Nokia Aktiebolag and merged it with another affiliation named Finnish Cable Works Ltd. Each of the affiliations were truly met in 1967 and Nokia Corporation was thought of. This affiliation set up itself in the field of electronic and telecom arranging. During the 1960s the affiliation acquired enormous commitment with the get-together of PCs. In 1979 Nokia got together with Salora and was named Mobira Oy. The affiliation occupied with the new turn of events and social occasion of telephones for Nordic Mobile Telephony [8]. Nokia has made breathtaking advancements in portable interchanges. It brought innovations like Wideband Code Division Multiple Access (CDMA), General Packet Radio Services (GPRS), as the moveable moves third era (3G). Nokia has set up their state-of-the-art innovation and pattern settling way of life contributions while divulging their portable handset items. In 3G administrations, Nokia will give email, climate data maps, defeat arranging, traffic data, ledger information, sees, travel data [9].

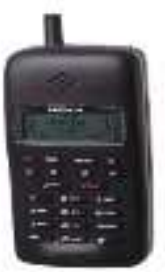

Fig. 1: Nokia 1011, First GSM Phone [10]

In October 1998, Nokia transformed into the first-class phone brand in the world. The functioning advantage was \$ 1 billion of each 1995, down from \$ 4 billion out of 1999 [11]. In 1994, Nokia appeared the Indian remote market. The primary GSM acquire Quite some time was created utilizing Nokia 2110 cell. Exactly when Nokia entered India, media correspondences approaches were not useful for the advancement of the wireless business. The cost on acquiring mobile phones were high as $27 \%$, even use charges was Rs.16/Minute as result customers didn't way to deal with purchase PDAs [12]. In 2003 the Nokia 1100 handset was dispatched. Close by the Nokia 1110 telephone, the 1100 was perhaps the best telephones of all time. Each sold 250 million contraptions all through the planet. Nokia dispatched the reliably green handset Nokia 1100 of each 2003 and it changed into the extraordinarily useful mobile phone until the end of time. A record of 250 million handsets were sold all through the world [13]. Nokia was a head of the Indian versatile handset industry for longer than 20 years [14]. The second era of tablet, N800, was carried out in January 2007. In October that very year, the third-generation, N810 opened up available. The working framework was moved up to Maemo 3, then, at that point, to version 4 [15].

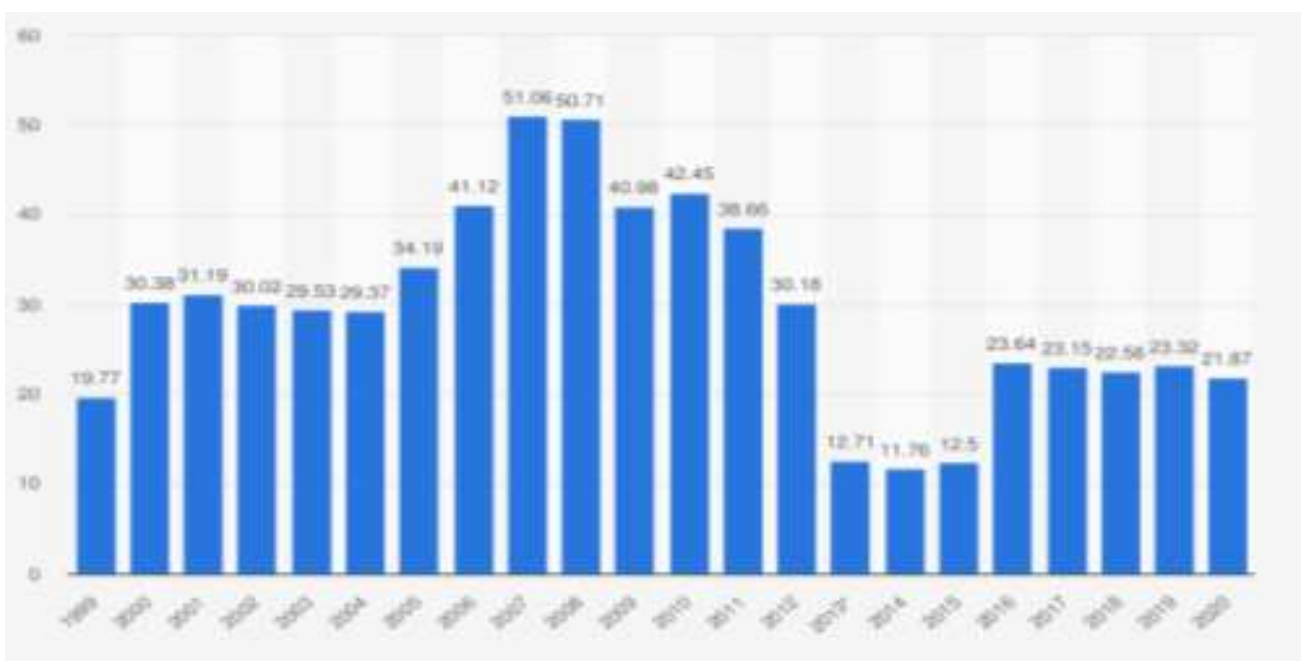

Fig. 2: Nokia net sales worldwide from 1999 to 2020 [16] 
In 2020 Nokia utilized 92.05 thousand individuals in around 131 areas around the world, incorporating around 39 thousand in Europe and a further 21 thousand in the Asia-Pacific district. In examination, Nokia 's net's turnover was most elevated in North America with 7.13 billion euros, where around 14\% of Nokia representatives are based, trailed by Europe with 6.62 billion euros [17].

\section{VERSIONS OF NOKIA HANDSETS :}

The following table gives an overview of the Nokia handsets Versions and their corresponding release date, and their latest stable version.

Table 2: Nokia handsets Versions [18]

\begin{tabular}{|l|l|l|}
\hline $\begin{array}{l}\text { Version } \\
\text { Name }\end{array}$ & $\begin{array}{l}\text { Release } \\
\text { Date }\end{array}$ & Features \\
\hline $\begin{array}{l}\text { Nokia } \\
1011\end{array}$ & 1992 & $\begin{array}{l}\text { First digital handheld phone for GSM, it had an extendible antenna and } \\
\text { was introduced the humble text messaging }\end{array}$ \\
\hline $\begin{array}{l}\text { Nokia } \\
2110\end{array}$ & 1994 & $\begin{array}{l}\text { First ever Nokia phone with the famous Nokia tune ringtone. It can send } \\
\text { and receive messages. Can list Ten dialed, missed and received calls, }\end{array}$ \\
\hline $\begin{array}{l}\text { Nokia } \\
8110\end{array}$ & 1996 & $\begin{array}{l}\text { Popularly known as a slider phone, the sliding cover protects the keyboard } \\
\text { when carried in the pocket and extends downward when in use, bringing } \\
\text { the microphone closer to the mouth }\end{array}$ \\
\hline $\begin{array}{l}\text { Nokia } \\
3210\end{array}$ & 1999 & $\begin{array}{l}\text { Internal antenna. Featuring phone calls, SMS and the influential game } \\
\text { Snake, }\end{array}$ \\
\hline $\begin{array}{l}\text { Nokia } \\
3310\end{array}$ & 2000 & $\begin{array}{l}\text { New Features were presented, for example, Chat work, mini-computer, } \\
\text { Nokia network screen, stop watch and an update work. It has four games: } \\
\text { Pairs II, Space Impact, Bantumi, and the tremendously well-known Snake } \\
\text { II. }\end{array}$ \\
\hline $\begin{array}{l}\text { Nokia } \\
1100\end{array}$ & 2003 & $\begin{array}{l}\text { Built-in flashlight, monophonic ringtones, SMS text messages, alarm } \\
\text { clock, reminders }\end{array}$ \\
\hline $\begin{array}{l}\text { Nokia } \\
\text { N91 }\end{array}$ & 2005 & $\begin{array}{l}\text { Top of the line music cell phone sports a 4 GB hard drive, music player, } \\
\text { 3.5mm headset jack, sound system FM radio, and devoted music keys. } \\
\text { Availability incorporates Wi-Fi, Bluetooth, and USB 2.0 with mass } \\
\text { stockpiling mode. Different provisions incorporate a 2-megapixel camera, } \\
\text { speakerphone, Flash player, and EDGE information. }\end{array}$ \\
\hline $\begin{array}{l}\text { Nokia } \\
5310 \\
\text { Xpress } \\
\text { Music }\end{array}$ & 2006 & $\begin{array}{l}\text { Introduced New Features such as 3 music buttons: Play, Next Track and } \\
\text { Previous Track. 3 music buttons: Play, Next Track and Previous Track. }\end{array}$ \\
\hline $\begin{array}{l}\text { Nokia } \\
5800 \\
\text { Xpress } \\
\text { Music }\end{array}$ & 2008 & $\begin{array}{l}\text { Symbian Operating System based, music-arranged capacitive touchscreen } \\
\text { semi cell phone and convenient diversion gadget }\end{array}$ \\
\hline $\begin{array}{l}\text { Nokia } \\
\text { Lumia }\end{array}$ & 2009 & $\begin{array}{l}\text { Entry level Windows Phone 8 cell phone reported by Nokia (Microsoft) } \\
\text { Has many features such as GPS, HSDPA and Wi-Fi support }\end{array}$ \\
\hline
\end{tabular}

\section{NOKIA MILESTONES :}

- In 1998 October, Nokia transformed into the top-selling PDA brand in the world.

- Nokia 's working advantage rose from $\$ 1.0$ billion out of 1995 to nearly $\$ 4.0$ billion out of 1999.

- In 2003, the smash hit mobile phone Nokia 1100 was created.

\section{COMPARISON OF MOBILE OPERATING SYSTEMS :}

PDA working framework is a working framework is used in cell phones. This working system are on a very basic level a light weight working structure which required low space and memory. Flexible working system in any case called compact OS this functioning structure can in like manner be used in 
PDA, Tablet, and Smartphone, etc. Versatile working structure merges all of the parts of PC. Adaptable working structure have all of the essential parts are according to the accompanying: - a touchscreen, cell, Bluetooth, Wi-Fi, GPS convenient course, camera, camcorder, talk affirmation, music player, voice recorder, near handle correspondence and infrared blaster [19]. Android is a Linux based working framework created by google/open handset partnership. It is a free and open source working framework. Symbian is a relative of Symbian OS which was created by Symbian Foundation. Symbian 3 is the most recent rendition was utilized in Nokia N8. Blackberry OS is a QNX(Unix-like) based working framework created by Blackberry Ltd. Windows telephone is a windows CE 7/windows NT 8 based working framework created by Microsoft. iOS is a Darwin based working framework created by Apple, Inc [20].

The below table point out the key differences between Symbian, Android, IOS and windows mobile operating systems. Apple sells under $20 \%$ of the cell phones yet takes in $92 \%$ of the worldwide cell phone benefits. The below table provides the basic difference between various operating systems.

Table 3: Nokia's Symbian Vs Google's Android Vs Apple's iOS Vs Microsoft's Windows mobile operating systems [21].

\begin{tabular}{|c|c|c|c|c|}
\hline $\begin{array}{l}\text { Parameters of } \\
\text { Comparison }\end{array}$ & Symbian & Android & iOS & Windows \\
\hline Release & June 5,1997 & $\begin{array}{l}\text { September 23, } \\
2008\end{array}$ & June 29, 2007 & 21 October 2010 \\
\hline Developer & Symbian Ltd. & Google & Apple & Microsoft \\
\hline Programming & written in $\mathrm{C}++$ & Written in Java, & $\begin{array}{l}\text { written } \\
\text { C, C++ and Apple's } \\
\text { own language, Swift. }\end{array}$ & Written in $\mathrm{C}$ \\
\hline Kernel Version & microkernel & Linux kernel. & XNU, based on Unix & Windows kernel \\
\hline Device & $\begin{array}{ll}\text { mainly } & \text { for } \\
\text { keypad } & \\
\text { devices } & \\
\end{array}$ & $\begin{array}{ll}\text { mainly } & \text { for } \\
\text { touchscreen } & \\
\text { devices } & \\
\end{array}$ & $\begin{array}{l}\text { mainly for } \\
\text { touchscreen devices }\end{array}$ & $\begin{array}{ll}\text { mainly } & \text { for } \\
\text { touchscreen } & \\
\text { devices } & \\
\end{array}$ \\
\hline Software & $\begin{array}{l}\text { Closed-source } \\
\text { software. }\end{array}$ & $\begin{array}{l}\text { open } \text {-source } \\
\text { software. }\end{array}$ & $\begin{array}{l}\text { Closed-source } \\
\text { software. }\end{array}$ & $\begin{array}{l}\text { Closed-source } \\
\text { software. }\end{array}$ \\
\hline Latest Version & $\begin{array}{l}\text { latest version } \\
\text { was released in } \\
\text { October } 2012 .\end{array}$ & $\begin{array}{l}\text { Android } 11, \\
\text { release in } 2021\end{array}$ & $\begin{array}{l}\text { iOS } 14, \text { released in } \\
\text { May } 24,2021\end{array}$ & Windows 10 \\
\hline
\end{tabular}

\section{REASONS BEHIND NOKIA FAILURE (2007-2012) :}

We didn't do anything incorrectly, yet by one way or another, we lost ". In 2013, then, at that point Nokia CEO Stephen Elop offered this expression prior to offering it to Microsoft for a $\$ 7.1$ billion arrangement. Nokia was once the world innovator in cells. Nonetheless, they couldn't stay aware of their inheritance. From 2007 to 2010, they encountered a slow decrease in their deals. There are number of variables and key blunders that caused Nokia 's inability to conform to changes in customer interest and completely new serious climate. Most remarkably in 2006 Nokia chose to move its concentration from cell phones back to include cell phone. However, the mobile phone industry began to experience a focal change during the completion of first decade of the 21st century. Nokia Dominated the mobile phone market until 2007 in view of Symbian Operating System. Nokia Market share ricocheted from $33 \%$ to $36 \%$ in just two months by introducing N95 series. Nokia holding $70 \%$ part of the general business leaving its opponents.

\section{Reasons for Downfall of Nokia:}

\section{- The Resistance to Smartphone Evolution:}

Nokia fail to take advantage of the Android pattern. This was the start of its ruin. While other PDA fabricates were occupied with further developing their PDAs Nokia remained difficult. Exactly when mobile phone makers were busy with improving and moving from keypad to contact screen, Nokia remained obstinate Nokia's affiliation was under the propensity that people wouldn't see contact screen telephones and would continue with the keypad plan. 
- Symbian Operating System Failure: At the point when Symbian 60 series was first presented in 2002 it ended up being exceptionally popular at first. Notwithstanding, Symbian OS needed applications and User Interface. Subsequently, development of iOS in 2007 and Android in 2008 gave hardened rivalry to Nokia's Symbian innovation.

- Didn't Analyze the Market Accurately: Nokia was consistently well known for its hardware equipment and didn't give a great deal of thought towards programming line-up Nokia started to focus on products and technology by ignoring the requirements of users. Decision framing wasn't based on users' requirements which lead Nokia to lose its grip from the cell phone market

- Bad Product Layout: Nokia's terrible item design and having its primary main focus on Windows as its operating system, lead to its decay.

- Satisfaction and Fear of Change: The sensation of Satisfaction that Nokia had of itself was really one of the primary motivations to its market disappointment. at the point when Apple dispatched the iPhone in 2007, which was the essential touch screen phone that overwhelmed everyone, Nokia was meanwhile putting earnestly in its E-series ignoring how another thought has truly changed the manner in which a wireless should be. The iPhone's victory didn't actually influence Nokia conversely, with for example Samsung that quickly advanced to mobile phones. In this way, Nokia neglected to comprehend and adjust to another change.

- Strategy: In June 2008, Nokia acquired Symbian Ltd. under a choice to make the Symbian OS opensource stage with the target that more experts can utilize it to develop their versatile applications. In February 2010, it was formally made open as open-source code. Regardless, it was absurdly late as Android, which was by then open-source and uninhibitedly accessible, and iOS has now begun to eat into Symbian market pie with their huge level stages and a monster number of help applications on the PDAs.

- Lack of Innovation: Nokia's absence of development was likely the main explanation on why it had a huge market disappointment, the way that Nokia just didn't get a handle on the new idea of having a product with unlimited applications and new encounters and that equipment didn't really matter however much it did before carried Nokia to disappointment. While brands like Samsung and Apple arranged progressed telephones each year. Nokia basically dispatched the windows telephone with significant parts yet even fell because of nonattendance of presentation of Symbian series by Nokia in 2002 had a decent market reaction. Be that as it may, with the presentation of Apple IOS in 2007 and Android in 2008, the OS race was totally taken over by the two goliaths. Nokia overpowered the market because of its standard arrangements phone, web enabled and media phone. However, the Symbian OS didn't get a ton of reputation among the shoppers [21].

- Political issues of Middle Management: Senior pioneers ought to include in setting the bearings to make client center business with clear and apparent authoritative qualities and hierarchical assumptions to all partners of the association [22].

- Fail to carry out the right umbrella marketing procedure: The affiliation followed an inadequate plan of umbrella checking. Apple viably applied the umbrella truly looking at model with the iPhone at the top. It kept on resuscitating new models to this umbrella a principal long time after year. Samsung followed a close to course by dispatching the Samsung Galaxy series yet Nokia excusal to take prompts.
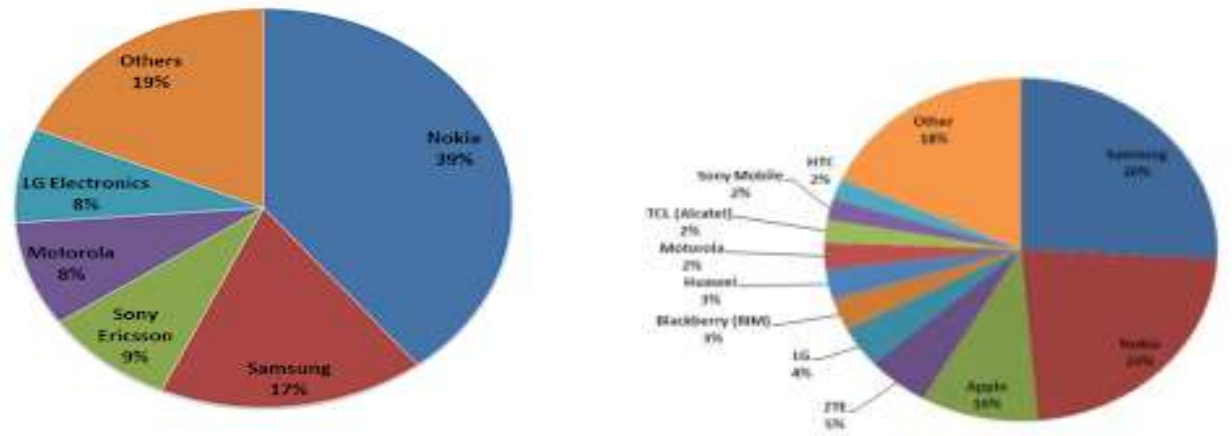

Fig. 3: (A) Smartphone Companies Market Share 2008. (B) Smartphone C Companies Market Share 2012 [23]. 
From the above Figure A and B Its clearly understandable that Nokia started losing its market from $39 \%$ to 23\% . in phone market from 2008, after Apple and Samsung introduced iOS and android based phones respectively.

\section{NOSTALGIC MARKETING APPROACH STRATEGY :}

Sentimentality was shaped by two Greek words for instance "nostos" means "get back or to one's nearby land" and "algos" connotes "desolation, suffering, or hopelessness". Johannes Hofer, in 1688 first time introduced the word nostalgia in quite a while hypothesis offered to Johannes Harder, a Doctor of Philosophy in like manner, Medicine and Professor of Anatomy and Botany at the University of Alsace. He was the principal character to depict thoughtfulness as a clinical circumstance and portrayed as "a troublesome yearning to get back" or mental explanation for "pining to return home". However, in later time it was described even more thoroughly, nostalgia insinuates an aching for the past, or a warmth for significant or subtle resources and activities associated with the past, and is fit when individuals feel segregated from a period to which they are associated. That tendency or feeling can be connected with fulfillment or pity [24].

\subsection{Companies employed Nostalgia Marketing Techniques :}

- Pepsi: Pepsi is a routine reprobate of Nostalgia Advertising methodologies. Pepsi not simply summons insightfulness from its long picture history (like Coke), yet it similarly praises its various insubordinate advancements. It has even "threw back" to its large name endorsers' jobs, for instance, Beyoncé in that 2014 Pepsi business wherein present-day Beyoncé moves off against more settled striking Beyoncé embellishments [25].

- Bacardi: The Bacardi brand has reliably been about enthusiastic social occasions; honestly, the current progressed advancement with the smooth Main Lazer track and insane dance changes is a advancing, their one fifty year celebration ad from 2011 showed a cavorting party from a more settled period to exhort us that Bacardi has been at the center of most get-togethers for more than a century.

- Calvin Klein: Calvin Klein in 2014, Calvin Klein obvious to summon some huge 90s sentimentality showcasing approach into their commercial campaigns - terrible dad pants what not. The primary advancements included Marky (Mark Wahlberg) and Kate Moss, while the new commercials Best featured Lottie Moss, Kate Moss' sister caught by the main advancements' visual craftsman's grandson [25].

- Adidas: The ascending of athleisure can be credited to the c appendage in notoriety of the Stan Smith shoe frenzy. Customarily, Adidas was pleasingly shocked that a more pre-arranged shoe of theirs had acquired a religion status, so they chose to attempt to bring back another work of art - the Gazelles. They expected to pull on the insightfulness strings while giving it another appeal. The outcome was a smooth progression set forth in a joint endeavor with questionable media synthesis talented specialist - Doug Abraham (of the now destroyed @bessnyc Instagram account), who took pictures from the notable Kate Moss business and redid it. It was propelling gold as Gazelle deals shot up.

\subsection{Nostalgic products can be of following types:}

Senior Products denotes to the items existing in past time are proceeded or re-dispatch after long time period to bring out wistfulness sensation of past time related with brand.

Custom-made Products denotes to the old period item, which are adjusted in current time to keep up with nostalgic snapshot of association in that specific brand.

New Product denotes to new item advancement centering nostalgic sensation.

The above table 3 demonstrates nostalgic products types and gives examples: 
Table 4: Nostalgic products [25]

\begin{tabular}{|l|l|}
\hline Nostalgic products Types & Examples \\
\hline Senior Products & $\begin{array}{l}\text { Galleries, Relaunch of widespread old movie songs, } \\
\text { Cadbury's Wispa bar }\end{array}$ \\
\hline Custom-made Products & $\begin{array}{l}\text { hum Dono (Rangin) Movie, Remix collections of old } \\
\text { melodies, Recent photographs in Black and white } \\
\text { example, Old Drama played with new craftsman }\end{array}$ \\
\hline New Product & $\begin{array}{l}\text { ZoomIn.com Photos (Create Account and all transferred } \\
\text { photographs will be put something aside for long life and } \\
\text { you can take print duplicates by request }\end{array}$ \\
\hline
\end{tabular}

\section{RETURN OF NOKIA USING NOSTALGIC MARKETING APPROACH :}

"A modern classic reimagined." This is the slogan for the "new" gadget from telephone producer Nokia used. The Finnish organization returned to the planning phase for its most recent line of telephones, one of which adheres intentionally near its unique plan: the Nokia 3310.

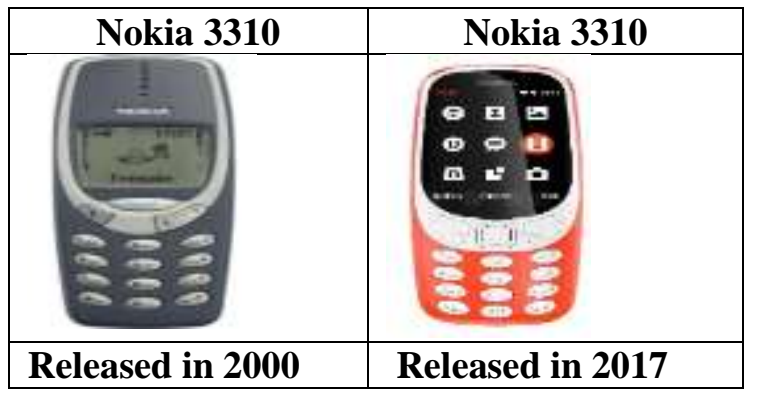

Fig. 4: Old Nokia 3310 and New Nokia 3310 [26]

With the arrival of the solid Nokia 3310, retro is back in the cell phone gadget fragment. HMD Global, the Finnish telephone producer, which holds the permit for making Nokia telephones, on Sunday rebooted the famous telephone best associated with the Snakes game with new components while possession the element telephone typical unblemished. Below table demonstrates the features of retro Nokia 3310 and modern Nokia 3310.

Table 5: Key difference between Retro and modern Nokia 3310 [27].

\begin{tabular}{|l|l|l|}
\hline Features & Retro Nokia 3310 & Modern Nokia 3310 \\
\hline Design & $\begin{array}{l}113 * 48 * 22 \mathrm{~mm}, 133 \text { grams of } \\
\text { weight }\end{array}$ & $115.6 * 51 * 12.8 \mathrm{~mm}, 79.6$ grams of weight \\
\hline Display & $\begin{array}{l}84 * 48 \quad \text { pixels,65 pp., } \\
\text { Monochrome LCD }\end{array}$ & $240 * 320$ pixels, color LCD \\
\hline Connectivity & No Bluetooth, No Wi-fi & $\begin{array}{l}\text { Micro-USB, Bluetooth, 3.5 mm jack, MicroSD, } \\
\text { FM radio }\end{array}$ \\
\hline Camera & No camera & 2 MP with LED flash \\
\hline Battery & $\begin{array}{l}900 \text { mAh detachable battery, 55 } \\
\text { hours standby, 2.5 hours of talk } \\
\text { time }\end{array}$ & $\begin{array}{l}900 \text { mAh detachable battery, 31 hours standby, } \\
22 \text { hours of talk time }\end{array}$ \\
\hline
\end{tabular}

The below figure demonstrates handset shipments of Nokia from III quarter 2017 to I Quarter of 2021 


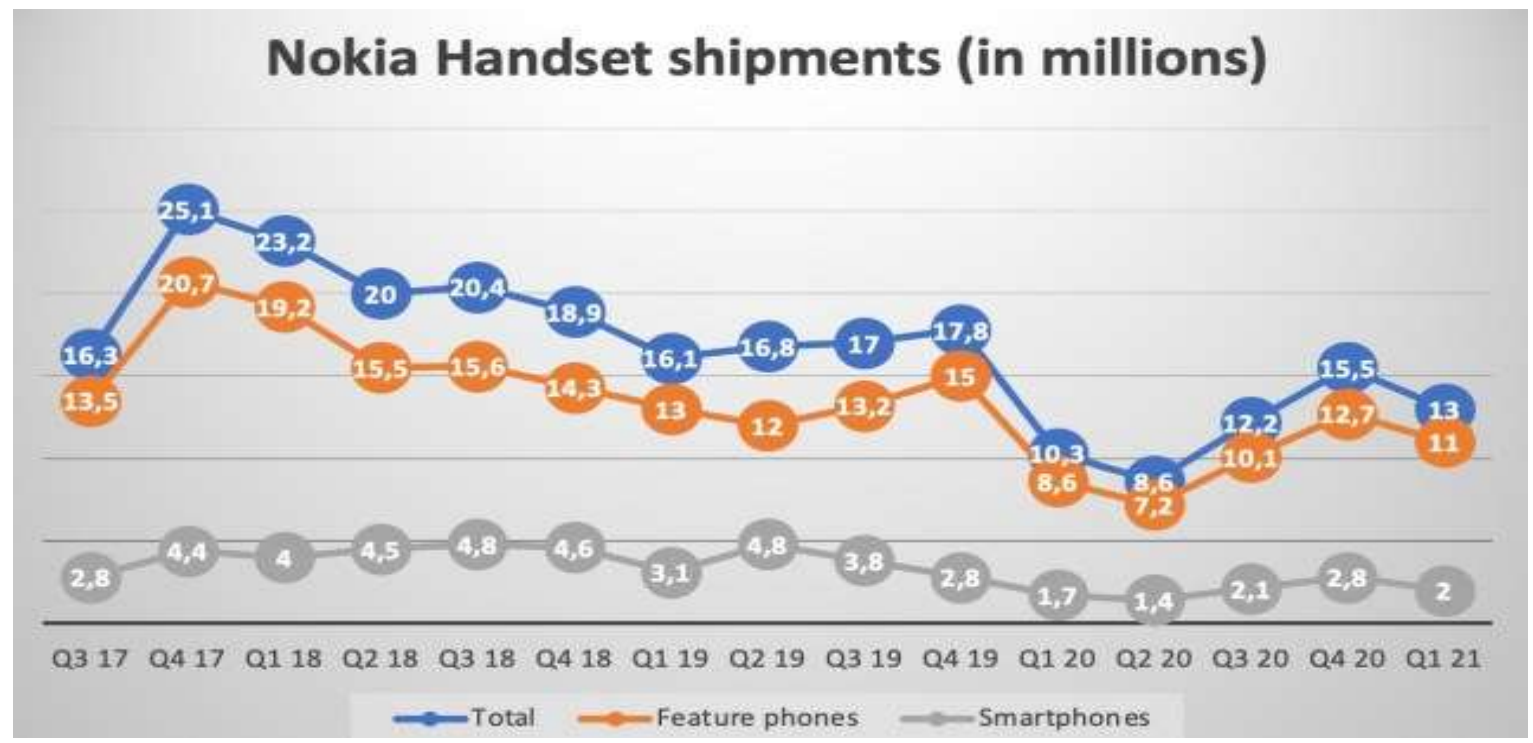

Fig. 5: Nokia Phones Shipment (in millions) from 2017 to 2021 [28].

In the primary quarter of 2021, that ranges from January to end of March, Nokia Mobile dispatched around 13 million Nokia telephones across the world. The shipment of cell phones almost arrived at 2 million during Q1 2021, contrasted with 1.6 million in a similar period last year, with Africa and portions of Europe being the development drivers. Contrasted with Q4 2020, the shipment diminished from around 2.8 million units. India as the market with most prominent alteration in consignments, where Nokia telephones encountered a 38.4\% decrease contrasted with Q4 2020 (QoQ) and a 17\% decay contrasted with Q1 2021 (YoY) [28].

The subsequent are four parts of Nokia 's promotion program that have worked with its rebound.

- Focused on Seamless Software Updates/ Enhance Performance: The invention rejuvenates help with working with both speedy working system and security revives. The result is a quality experience for the customer at an open worth point.

- A strong Product Offering at a Good Price: Nokia saw an opening in the mid-range section of the telephone market and set off to offer sturdy and solid gadgets at sensible costs

- Quick in getting the product to market: Nokia has effectively abbreviated new item presentation cycles, empowering it to come out with new items more quickly than contenders. In the first eight months of 2019, the firm launched five devices. This speed to advertise with advancements for the designated section, has most likely been a factor in the organization's prosperity.

- Focused on effective partnership: The cell phone industry is unpredictable in that associations with providers, transporters, and retailers are instrumental to both new item improvement and dispersion. On the retail side, HMD Worldwide has combined with enormous retailers including Amazon and Best Purchase, among others. As far as transporters, the organization presently has standing joint efforts with driving remote suppliers in the U.S. counting Cricket Remote, AT\&T and Verizon.

\section{SWOC ANALYSIS :}

SWOC analysis is an essential arranging technique used to investigate outer and inward factors which influence organization achievement and development. firms use SWOC analysis [29-35] to decide the qualities, shortcomings, openings, and difficulties of their firm, items, and rivalry.

\section{Strengths:}

- Since Nokia is perhaps the most established organization in the world. It has acquired dense knowledge and data about the business areas all throughout the world. Its brand is its strength. 
- Nokia has the most knowledgeable and mechanically progressed persons in its labour force. In the field of versatile and cell phones, it has added confidence by giving excellence phones. Without an effective labor force and aptitude, it would not occur

- Nokia has been giving various types of things to its market and have additionally been taking client investigation. By this, they have been making solid information bas

- Nokia has a tremendous and strong telecom station. To scatter its things through the countries of South Asia, it has set up customer care centers and retail shops to sell its phones.

- The products Nokia manufactures and trade have a reliable standing. Hence, the trade regard remains high. Along these lines, when an individual b0uys a thing from Nokia, they understand they can sell it at an extreme expense if they need to do it in future

\section{Weakness:}

- In the developing market, Nokia has been incredibly slow to demonstrate a desire to be more serious in this area. Furthermore, they have not entered any of the field's small-scale competitions. This is why Nokia was unable to compete with Apple and Samsung in 2007.

- Nokia is not very much delicate and receptive to the new changes to client assumptions.

- After sale, service is poor. Because they own very few service centers.

- Nokia consumed much amount of time to release high productive smartphone market,

\section{Opportunities:}

- Mobile phone market is growing, it is right opportunity for Nokia to re-conquer the lost market by producing smartphone according the latest trends to become a Trent Setter.

- Every country is moving towards digitalization, Nokia must recatch this chance to sell and expand its market all over the market.

- To Explore more in the space of distributed computing and capacity to build the User Experience [36].

- The Nokia Corporation might have the option to take advantage of new business sectors because of recent fads in buyer conduct. It offers the organization a gigantic chance to create new income streams and venture into other item classes.

\section{Challenges:}

- The company must become more responsive, focusing on high-end smartphones, application processors, and its app store.

- Many mobile manufactures have started producing high end smart phone for low cost selling price.

- Since world is moving towards digitalization, should be Concentrate on rural parts of the world

- Retaining the lost market is the biggest challenge, by manufacturing phones as per the requirement of customers can gain the confidence and lost market.

- Dependence on online business as the primary appropriation channel [37].

\section{SUGGESTIONS :}

- Nokia should do a 360-degree analysis of the present market condition and developments, as well as a 360-degree study of its own. Nokia should examine all aspects of present customer demand and need.

- Innovation is the only key to regain its glory, If Nokia want to recover its glory, they must increase innovation activities.

- Growing brand upgrade and support its brand in customers mind, with this Nokia can build its repo in the market.

- Nokia must step into new business plan and marketing strategy, Implementing umbrella brand strategy.

\section{FINDINGS OF THE STUDY :}

In this paper, we have analyzed, reviewed and identified the major reasons for the downfall of Nokia. Firstly, we analyzed the history of Nokia, then reviewed its various versions of its products against the features, later we identified various reasons which caused Nokia to lose its legacy. It is found that Nokia 
didn't/Failed to analyze the smartphone market and became unsuccessful to understand the need of then customers. It's lack of innovation is also a major reason to lose its legacy. In 2017 Nokia came with nostalgic marketing approach by re-creating its old Nokia 3310 handset with modern features such Bluetooth, GPS, Wifi. With the help of SWOT analysis, we mentioned its strengths, weakness, Opportunities and possible threats.

\section{CONCLUSION :}

Nokia was truly well known for its real interface plan and other ergonomic parts of its cells. They were inventive especially in compacting an especially tangled genuine interface plan into a little adaptable mechanism. Due to lack of strategy, slow moving in implement innovative technology and good forecasting it lost its market from 2007. This investigation paper originally presented the History of Nokia, then analyzed the features of Nokia smartphones with its rivalries such as Apple, Samsung. After that, this research paper reviewed the reasons for Nokia's fall down, later this article came across Nostalgic Marketing Approach which Nokia used by introducing its vintage brand Nokia 3310 to regain its glory in the smart phone market. This article also suggested plans to brand its smartphone in the market.

\section{REFERENCES :}

[1] Cha, S. S., \& Seo, B. K. (2018). Smartphone use and smartphone addiction in middle school students in Korea: Prevalence, social networking service, and game use. Health Psychology Open, 5(1), 15 .

\section{Google Scholar $x^{7}$}

[2] Chaturvedi. (2017). Analysis of Decline Market: With Special Reference to Nokia Phone. International Journal of Engineering Research and Development, 13(9), 22-27.

Google Scholar X

[3] Bhalodiya, N., \& Sagotia, N. (2018). Reasons behind the failure of Nokia: a Case study of Telecom sector. International Journal of Management and Humanities, 5(03), 14-18.

Google Scholar $X^{\top}$

[4] Neelu. (2014). A Study on Nokia. International Research Journal Commerce Arts Science, 5(6), 47-57.

Google Scholar $x^{7}$

[5] Sehrawat, S. (2019). Risk management strategies in large telecom companies: with special reference to Nokia. International Journal of Advanced Scientific Research and Management, 4(2), 99-103. Google Scholar X

[6] Hira, A. (2012). Secrets behind the Finnish miracle: the rise of Nokia. International Journal of Technology and Globalization, 6(1/2), 38-64.

Google Scholar 7

[7] Laamanen, T., Lamberg, J. A., \& Vaara, E. A. (2014). Explanations of success and failure in management learning: what can we learn from nokia's rise and fall?. Academy of Management Learning \& Education, 15(1), 1-43.

Google Scholar $x^{7}$

[8] Sulphey, M. (2019). Could the Adoption of Organizational Ambidexterity Have Changed the History of Nokia?. South Asian Journal of Business and Management Cases, 8(2), 1-15.

Google Scholar $X^{7}$

[9] Bhatt, P. R. (2002). Internationalization and Innovation: A Case Study of Nokia. Vision: The Journal of Business Perspective, 6(2), 121-129.

Google Scholar $X^{7}$

[10] Kalyani P. (2017). Re-Birth of Nokia in 2017 - An Empirical Study of Nokia's Nostalgic Marketing Strategy with Special Reference to a Pre-Launch Scenario in India, Journal of Management Engineering and Information Technology, 4(2), 31-43. Google Scholar X 
[11] Ciesielska, M. (2017). Nokia on the slope. The International Journal of Entrepreneurship and Innovation, 19(3), 218-225.

Google Scholar ${ }^{7}$

[12] Bidyarthi, H. M. J., Srivastava, A. K., Bokad, P. V., \& Deshmukh, L. B. (2011). Nokia's strategies in Indian mobile handsets markets during 2002 to 2006. International Journal of Technology Marketing, 6(2), 177-188.

Google Scholar ${ }^{7}$

[13] Bouwman, Harry et al. (2014). How Nokia failed to nail the Smartphone market, 25th European Regional Conference of the International Telecommunications Society (ITS), Brussels, Belgium, $1-18$.

Google Scholar X

[14]Ciesielska, M. (2017). Nokia on the slope: The failure of a hybrid open/closed source model. The International Journal of Entrepreneurship and Innovation, 19(3), 1-8. Google Scholar $x^{7}$

[15] Tyagi, P., \& Zaidi, Neha. (2019) Nokia's Comeback — Is it Revival of an Iconic Brand? Asian Case Research Journal, 23(1), 415-426.

Google Scholar $x^{\top}$

[16] Thomas Alsop. (2021). Nokia net sales worldwide from 1999 to 2020. Retrieved from https://www.statista.com/statistics/267819/nokias-net-sales-since-1999/ Accessed on: 21-07-2021

[17] Devashish Shrivastava (2021). 6 reasons why Nokia failed after enjoying Unrivaled Dominance. Retrieved from https://startuptalky.com/reasons-why-nokia-failed/\#TheDealWithMicrosoft Accessed on 22-07-2021

[18] Neha Borkar (2016) .15 Epic Old Nokia Phones That We Will Always Remember. Retrieved from https://www.indiatimes.com/culture/who-we-are/15-epic-old-nokia-phones-that-we-wil-alwaysremember-255397.html Accessed on 25-07-2021

[19] Bharati Wukkadada, Ramith Nambiar, Amala Nair (2015). Mobile Operating System: Analysis Comparison of Android and iOS. International Journal of Computer Applications Technology and Research, 2(7), 273-276.

Google Scholar $x^{7}$

[20] Gregory F. Welch (1995). A survey of power management techniques in mobile computing operating systems. ACM SIGOPS Operating Systems Review, 29(4). 47-56.

Google Scholar $\chi^{7}$

[21] Ribeiro, A. and da Silva, A. R. (2012). Survey on Cross-Platforms and Languages for Mobile Apps. Eighth International Conference on the Quality of Information and Communications Technology, 255-260.

Google Scholar X

[22] Aithal P. S. (2021). Business Excellence through the Theory of Accountability. International Journal of Case Studies in Business, IT and Education (IJCSBE), 5(1), 88-115. Google Scholar X

[23] Salman Abdou, D. M., \& Hussein, R. (2020)., lack of innovation led to Nokia's failure? How fear of change. International Journal of Business Ecosystem \& Strategy, 2(4), 43-48.

Google Scholar $x^{\top}$

[24] Hartmann, B., \& Brunk, K. (2019). Nostalgia marketing and (re-)enchantment. International Journal of Research in Marketing, 36(4), 669-686.

Google Scholar ${ }^{\top}$

25] Sadia Sarwar. (2018). 13 Brands That Are Using "Nostalgia Marketing" and Why It's Working Brilliantly. Retrieved from https://startupmindset.com/13-brands-that-are-using-nostalgiamarketing-and-why-its-working-brilliantly Accessed on 25-07-2021 
[26] John McCann (2017). New Nokia 3310 vs original Nokia 3310: which phone is king? Retrieved from https://www.techradar.com/in/news/new-nokia-3310-vs-original-nokia-3310-which-phoneis-king Accessed on 21-07-2021.

[27] Maji, A. K., Hao, K., Sultana, S., \& Bagchi, S. (2010). Characterizing Failures in Mobile OSes: A Case Study with Android and Symbian. IEEE 21st International Symposium on Software Reliability Engineering, 2010, pp. 249-258.

Google Scholar $\chi^{\top}$

[28] Vainio-Mattila, K., \& Ruuska, S. (1999). Design: Designing mobile phones and communicators for consumer needs at Nokia. Interactions, 6(5), 23-26.

Google Scholar X

[29] Aithal, P. S., \& Kumar, P. M. (2016). Analysis of Choice Based Credit System in Higher Education. International Journal of Engineering Research and Modern Education (IJERME), 1(1), 278-284.

Google Scholar $X^{7}$

[30] Aithal, P. S., \& Kumar, P. M. (2015). Applying SWOC analysis to an institution of higher education. International Journal of Management, IT and Engineering, 5(7), 231-247.

Google Scholar X'

[31] Aithal, P. S. and Suresh Kumar, P. M., (2016). Theory A for Optimizing Human Productivity. IRAInternational Journal of Management \& Social Sciences, 4(3), 526-535.

Google Scholar Х

[32] Aithal, P. S. (2017). Industry Analysis-The First Step in Business Management Scholarly Research. International Journal of Case Studies in Business, IT and Education (IJCSBE), 1(1), 113.

Google Scholar $\chi$

[33] Sigma Sathyan, \& Jagadeesha S. N. (2021). 100 Years of Growth and Success Story of Nestle India - A Fast Moving Consumer Goods (FMCG) Industry. International Journal of Case Studies in Business, IT and Education (IJCSBE), 5(2), 226-238.

Google Scholar X

[34] Aithal, P. S. (2017). An effective method of developing business case studies based on company analysis. International Journal of Engineering Research and Modern Education (IJERME), 2(1), 16-27.

Google Scholar X

[35] Aithal, Shubhrajyotsna \& Aithal, P. S. (2016). Student centric learning through planned hard workan innovative model. International Journal of Scientific Research and Modern Education (IJSRME), 1(1), 886-898.

Google Scholar $\chi^{\top}$

[36] Thomas C. G., \& A. Jayanthila Devi. (2021). Study and Analysis of the Influence of UX in MIUI - A Case Study on Xiaomi. International Journal of Case Studies in Business, IT and Education (IJCSBE), 5(1), 155-168.

Google Scholar $x^{7}$

[37] Shylesh S. (2019). Analysis of Business Strategies of Xiaomi. International Journal of Case Studies in Business, IT, and Education (IJCSBE), 3(1), 1-8.

Google Scholar X 